\title{
Antimicrobial effects of Coleus amboinicus, Lour folium infusum towards Candida albicans and Streptococcus mutans
}

\author{
Devi Rianti and Sri Yogyarti \\ Department of Dental Material and Technology \\ Faculty of Dentistry Airlangga University \\ Surabaya - Indonesia
}

\begin{abstract}
A laboratory experimental study conducted on antimicrobial effects of Coleus amboinicus, Lour folium Infusum towards Candida albicans and Streptococcus mutans (S. mutans). Effective concentration of Coleus amboinicus, Lour to decrease the quantities Candida albicans and S. mutans colonies is expected to be found out in this study. This study was using Coleus Amboinicus, Lour folium infusum with $12.5 \%, 15 \%, 17.5 \%, 20 \%$, and $22.5 \%$ concentrations. Sterilized aquadest used as a control. Candida albicans and $S$. mutans quantities was enumerated by counting the amount of Candida albicans and S. mutans growth in the Sabouraud's dextrose agar and Tryptone and yeast Agar media, using Colony Forming Unit per milliliter (CFU/ml) unit. Data analysis was using a One-Way ANOVA and LSD with 5\% degree of significance. The result showed $22.5 \%$ concentration of CAL folium infusum was the most effective in decreasing the quantity Candida albicans and S. mutans colonies.
\end{abstract}

Key words: antimicrobial, coleus amboinicus, lour, candida albicans, streptococcus mutans

Correspondence: Devi Rianti, c/o: Bagian Ilmu Material dan Teknologi Kedokteran Gigi, Fakultas Kedokteran Gigi Universitas Airlangga. Jln. Mayjend. Prof. Dr. Moestopo No. 47 Surabaya 60132, Indonesia.

\section{INTRODUCTION}

According to national health system guidance, the traditional medication which can successfully, will be lead and used for research and examination literally to Indonesian herbs so it is safe to be used. Indonesian government supports the use of traditional materials as one of alternative medication, since Indonesia is enriched with medical herbs.

One of the herbs usually plant in the garden and easily growth is jinten leaf. According to Wijayakusuma et al. ${ }^{1}$ Jinten leaf in Latin called Coleus amboinicus, Lour and simplified as Plectranthi amboinicus folium, is a plant which peculiar for stomatitis and antifungal medication. The chemical contents of Coleus amboinicus, Lour are calium, essential oils which contains carvacrol, isoprophylo-cresol, phenol and sineol. Weehuizen ${ }^{2}$ stated, that from $120 \mathrm{~kg}$ fresh leaf of Coleus amboinicus, Lour (CAL) will be resulted essential oils such $25 \mathrm{ml}$, and $25 \mathrm{ml}$ essential oils equal to $0.2 \%$ essential oils which contains phenol generations, i.e. isoprophyl-o-cresol, which has high antiseptic effect. ${ }^{2}$ Preliminary examination of CAL showed, that from Tawangmangu Central Java chemical content, extracted with alcohol 96\%, it contains alkaloids, saponin, cardenolids, and bufadienolids together with polyphenol. ${ }^{3}$ Devi' ${ }^{4}$ experiment stated that extract solution of CAL is effective to decrease Candida albicans (C. albicans) in acrylic resin after 2 hours soaking with $15 \%$ concentration.

Chemical component sineol has antifungal effects to C. albicans, Trichiphyton metagrophytes and Cryptococcus neoformans..$^{5}$ Wisterich and Lechtman stated that Phenol and Cresol can kill fungus vegetative cell and bacteria by protein denaturation and surface tension reduction, so that increases bacteria permeability. ${ }^{6}$

Streptococcus mutans (S. mutans) is a normal occupant bacteria in oral, however if the atmosphere fits, and population increases it becomes pathogen. ${ }^{7}$ S. mutans have been admitted in the dentistry as the main cause of caries. ${ }^{7}$ Based on that, the growth of $S$. mutans should be obstructed to become pathogen.

According to Bahalwan and Sjahbana ${ }^{8}$ the use of traditional medication in Indonesia is as a prevention. Some of herbal traditional medication can be used as a mouthwash and they also work for antiseptic as if as a disinfectant are semanggi leaf, jinten leaf (CAL), sirih leaf, gambir, saga leaf and also kaca piring leaf.

Usually, extract materials are hard to find, the alternative ways to process the herbs are needed. In one of research, infusum technique for herbs is better than boiled. ${ }^{9}$ The advantage of infusum, is easier to use and it has been socialized, cheaper because there is no special treatment and complicated instrument is needed as well.

In some of literatures said, that CAL has an antiseptic character because of it chemical contents. Some of researches stated that it could decrease the growth of C. albicans, Trichiphyton metagrophytes and Cryptococcus neoformans, either ways there are some possibilities of CAL to have antibacterial character towards $S$. mutans. The best technique to use and to, reduce the cost and to be more socialized, the infusum technique is chosen. The minimum concentration of CAL folium infusum to decrease $S$. mutans and $C$. albicans colonies is unknown yet. The aims of this 
article is to investigate if CAL folium infusum concentration variations effect towards $C$. albicans and $S$. mutans colonies and to find the concentration of CAL folium infusum that has an effective antimicrobial character towards C. albicans and $S$. mutans.

\section{MATERIALS AND METHODS}

The research is an experimental laboratories and the research design is post test only control group. Independent variable is CAL folium infusum with $12.5 \%, 15 \%, 17.5 \%$, $20 \%, 22.5 \%$ concentration. Dependent variable is the amount of $C$. albicans and $S$. mutans colonies. The control variables are the similarity of planting area, crops time, drying time, temperature and time of $C$. albicans and $S$. mutans proliferation, growth media, counting $C$. albicans and $S$. mutans, and CAL folium infusum process, in accordance with Farmakope Indonesia. ${ }^{10}$ This research has been done in phytochemical Laboratory Faculty of Pharmacy Airlangga University, Oral Microbiology Laboratory Faculty of Dentistry Airlangga University, Surabaya.

Materials those being used in these research are C. albicans suspension, S. mutans, Sabouraud's dextrose media and Sabouraud's broth, Tryptone and Yeast Agar (TYC) media and Brain Hearth Infusion (BHI) and CAL leaf from central traditional medication research garden. Instruments to count $C$. albicans and $S$. mutans are: incubator (Precision, Japan), 0,2 $\mu \mathrm{m}$ milipore filter unit (Millex-HA, Bedford), reaction tube, stopwatch, petridish (Anumbra), autoclave (Foundry), ose, spreader, pinset, vibrator (Vortex), 5 cc injection syringe (Terumo), 1 cc tuberculine syringe (Terumo), Ependorff micropipette (Titertek, England), anaerobic jar, mechanic counter instrument (Hand Tally model H-102, Japan).

The research methods are making of CAL folium infusum in accordance with Farmakope Indonesia, and counting of $S$. mutans and $C$. albicans colonies. Counting $S$. mutans colonies is by preparing 7 reaction tubes and giving numbers by order 1 until 7. Reaction tubes 1 until 5 are filled with test materials i.e. $1 \mathrm{ml} \mathrm{CAL}$ folium infusum in $2 \mathrm{ml}$ Brain Hearth Infusion Broth (BHIB) media and $S$. mutans with a density of $3 \times 10^{8}$ that already liquefied by $10^{-7}$ as much as $0.1 \mathrm{ml}$. CAL folium infusum concentrations in reaction tubes number 1 until 5 are $22.5 \%$, $20 \%, 17.5 \%, 15 \%, 12$.

$5 \%$. Reaction tube number 6 is not filled with test material, but it is added with $S$. mutans with $3 \times 10^{8}$ densities that already liquefied as positive control. Reaction tube number 7 filled with only BHIB media without $S$. mutans as negative control. Ten times of replication are done. All of reaction tubes are placed in an anaerobic jar, in anaerobic environment and incubated as long as 24 hours on $37^{\circ} \mathrm{C}$. The result is read by observing whether there is a deposit or turbid. To count the $S$. mutans colonies, all test materials are planted in TYC media in petridish. Each of petridish is filled with the liquid in the tube (CAL folium infusum + BHIB media $+S$. mutans) using pipette which have the same number as the reaction tube, then spread using spreader at the surface of solid TYC media. All the petridish to put in anaerobic jar incubated in $37^{\circ} \mathrm{C}$ degree, as long as 48 hours. Result reading is by observing whether there is a colony proliferation at the surface of TYC, and counting the colonies $(\mathrm{CFU} / \mathrm{ml})$.

To count $C$. albicans colonies is by preparing 7 reaction tubes and giving numbers 1 until 7. Reaction tubes number 1 until 5 are filled with $1 \mathrm{ml} \mathrm{CAL}$ folium infusum in $2 \mathrm{ml}$ Sabouraud's broth media and with $C$. albicans density of $3 \times 10^{8}$ that already liquefied by $10^{-7}$ as much as $0,1 \mathrm{ml}$. CAL folium infusum concentrations in reaction tubes 1 until 5 are $22.5 \%, 20 \%, 17.5 \%, 15 \%, 12.5 \%$. Reaction tube number 6 is not filled with test material, but it is added with $C$. albicans which has $3 \times 10^{8}$ densities that already liquefied as positive control. Reaction tube number 7 filled with Sabouraud's broth media without $C$. albicans as negative control. Replications are done in ten times. The result is read by observing whether there is a deposit or turbid. To count the $C$. albicans colonies, all test materials are planted in Sabouraud's dextrose media in petridish. Each of petridish is filled with the liquid in the tube (CAL folium infusum + Sabouraud's broth media $+C$. albicans) using pipette which have the same number as the reaction tube, then spread using spreader at the surface of Sabouraud's dextrose media media. All the petridish to put in incubator, incubated in $37^{\circ} \mathrm{C}$ degree, as long as 48 hours. Result reading is by observing whether there is a colony proliferation at the surface of Sabouraud's dextrose media, and counting the colonies $(\mathrm{CFU} / \mathrm{ml})$.

The result is being tabulated according to each group then statistic test is held using One-Way ANOVA, with deviation degrees $5 \%$. However, if there is a significant result, it will be continued by LSD test.

\section{RESULTS}

The average result and standard deviation $C$. albicans and $S$. mutans colonies after contacted with CAL folium infusum in concentration $12.5 \%, 15 \%, 17.5 \%, 20 \%, 22.5 \%$ can be seen at table 1 and 2 .

Table 1. Average and Standard deviation from total C. albicans colony $(\mathrm{CFU} / \mathrm{ml})$ after contact with $\mathrm{CAL}$ folium infusum

\begin{tabular}{llrr}
\hline Concentration & $\mathrm{N}$ & $\overline{\mathrm{X}}$ & $\mathrm{SD}$ \\
\hline Control & 10 & 479.50 & 18.91 \\
$12,5 \%$ & 10 & 244.60 & 36.04 \\
$15 \%$ & 10 & 183.30 & 10.79 \\
$17,5 \%$ & 10 & 114.30 & 10.66 \\
$20 \%$ & 10 & 55.20 & 10.43 \\
$22,5 \%$ & 10 & 18.60 & 9.43 \\
\hline
\end{tabular}


Table 2. Average and Standard deviation from total S. mutans colony $(\mathrm{CFU} / \mathrm{ml})$ after contacted with $\mathrm{CAL}$ folium infusum

\begin{tabular}{llrr}
\hline Concentration & $\mathrm{N}$ & \multicolumn{1}{c}{$\overline{\mathrm{X}}$} & \multicolumn{1}{c}{$\mathrm{SD}$} \\
\hline Control & 10 & 495 & 42.52 \\
$12,5 \%$ & 10 & 286.80 & 30.36 \\
$15 \%$ & 10 & 233.40 & 26.66 \\
$17,5 \%$ & 10 & 165 & 11.24 \\
$20 \%$ & 10 & 120.30 & 13 \\
$22,5 \%$ & 10 & 55.70 & 12.09 \\
\hline
\end{tabular}

Notes: N: Samples amount $\quad$ X: Average $\quad$ SD: Standard deviation

Before parametric test is done, to know the significant difference result, a normality test using KolmogorovSmirnov test should be done. The result is, 5 treatment group and control are normally distributed ( $\mathrm{p}>0.05)$, moreover, comparison test to 5 treatment group and control is done by One-Way ANOVA test. From One-Way ANOVA test, it appears that there is a significant result among treatments with $\mathrm{p}=0.001(\mathrm{p}<0.05)$, to find out further the differences among treatments, the analysis is continued with Least Significant Difference (LSD) test. LSD test shows that there is significant result in each concentration groups; $12.5 \%, 15 \%, 17.5 \%, 20 \%, 22.5 \%$ and control. In other words the increase of CAL folium infusum concentration will affect $C$. albicans and $S$. mutans colonies.

\section{DISCUSSION}

The use of natural herbs medication has already been socialized and barely a new thing, but it has been exercised long time ago to fulfill the need of medication in solving health problem, and the experience has been inherited. The benefit is admitted by a lot of people, but still there is not lot of literatures.

Guided by national health system, it is stated that a useful traditional medication will be lead and used for some scientific research and test to Indonesian plants. One of traditional medication herbs that usually planted in the garden and easily to grow is jinten leaf, in latin it is called Coleus amboinicus, Lour (CAL), which have chemical content, phenol which is as an antiseptic. ${ }^{1,2}$ Preliminary examination on chemical content of CAL material from Tawangmangu Central Java filtered with alcohol 96\%, it is appears containing alkaloids, saponin, kardenolids, bufadienolids also polyphenol. ${ }^{3}$ Base on that, there are some possibilities those materials can be used for oral antimicrobial as antiseptic in dentistry.

Result from the research shows the average $C$. albicans and $S$. mutans colonies after contact with CAL folium infusum in increasing infusum concentration, i.e. $12.5 \%$, $15 \%, 17.5 \%, 20 \%, 22.5 \%$ will decrease. On the contrary, in lower concentration the total $C$. albicans and $S$. mutans colonies increased constantly.
This is caused by Coleus amboinicus, Lour contains phenol and phenol generations which are useful antiseptic. ${ }^{1,2}$ Supported from Devi research's, stated that, in dry CAL leaf extract contains $5.15 \%$ phenol and $3.65 \%$ sineol. ${ }^{4}$ Increasing CAL folium infusum concentration will cause decreasing $C$. albicans and $S$. mutans colonies, since the increased concentration will increase the phenol and sineol in infusum. The increased phenol and sineol, will increase the antimicrobial effect of infusum towards C. albicans and S. mutans. It is further explained by Regezi and Sciubba ${ }^{11}$ that $C$. albicans is a very sensitive species towards phenol. Besides phenol, Hammerschimdt et al. ${ }^{5}$ stated that the other chemical materials, sineol, also have antifungus activity towards $C$. albicans, Trichiphyton metagrophytes and Cryptococcus neoformans. Hugo and Rusell, ${ }^{12}$ stated that phenol generally can be used as disinfectant which have antimicrobial activity and fast bactericide, the activity usually decreased by watering. It is also supported by Siswandono and Soekarjo, ${ }^{13}$ who stated that materials effectiveness affected by concentration, time and temperature.

In these research, infusum $\mathrm{pH}$ is approximately between 4.78-4.80, which is possibly has good effect in antimicrobial activities of CAL folium infusum, since phenol appears more effective in acid $\mathrm{pH}$ and moreover, it is explained that disinfection process influenced by several factors such as, concentration, temperature, and $\mathrm{pH} .{ }^{12}$

Other factor which possibly the cause is the presence of alkaloid contents. Alkaloid is a chemical compound contains nitrogen, and this group can be diverged from other plant component based on its alkali characteristic. This compound is found in plant as salt of various organic acids, which is functioned to protect plant from parasites and predator, and also effective as antimicrobial. ${ }^{14}$

Until now, there still no references for antimicrobial mechanism of this alkaloid. Based on antimicrobial mechanism, phenol can eliminate fungus vegetative and bacteria by protein denaturation and surface tension reduction which caused the bacteria and fungus permeability are increased. ${ }^{6}$ It is explained by Melville and Russel ${ }^{15}$ that reaction with cell protein, is an obstruction or elimination process by ruining the colloid system using protein coagulation and precipitation. Microbial cell protein coagulation will cause metabolism distraction and membrane cell permeability change is by decreasing the surface tension which increase the membrane cell permeability causing liquid enters and eliminates the microbe.

Renner et al. ${ }^{16}$ proved that people using denture without pathologic change of its supporting mukosa orally, as if the $C$. albicans colonies are not more than $100 \mathrm{CFU} / \mathrm{ml}$. Candida species experiment will be decided as positive, if the amount is more than 100 colonies of subject samples with Sabouraud's dextrose breeding, or if the amount is more than $500 \mathrm{CFU} / \mathrm{ml}$ saliva. According to Brightman \& Greenberg ${ }^{17}$ C. albicans is assumed as a normal flora part in oral, as it can be found in some healthy individuals and 
carriers if it not more than $200 \mathrm{CFU} / \mathrm{ml}$, detected by oral swapping inoculation of Sabouraud's dextrose agar breeding. Average value of $C$. albicans colonies in this research are $244.60 \mathrm{CFU} / \mathrm{ml}, 183.30 \mathrm{CFU} / \mathrm{ml}, 114.30 \mathrm{CFU} /$ $\mathrm{ml}, 55.20 \mathrm{CFU} / \mathrm{ml}, 18.60 \mathrm{CFU} / \mathrm{ml}$ (Tabel 1), from contact with CAL infusion in $12.5 \%, 15 \%, 17.5 \%, 20 \%, 22.5 \%$ concentrations. C. albicans colonies which are contacted with CAL folium infusum with a $15 \%$ concentrate are less than total colonies of a healthy individual. From those scholars' research and opinion comparison, the use of $15 \%$ concentrate of CAL folium infusum is found has been effective to decrease the amount of $C$. albicans colonies.

In conclusion, increasing of CAL folium infusum concentration, i.e. $12.5 \%, 15 \%, 17.5 \%, 20 \%, 22.5 \%$ will decrease the total $C$. albicans and $S$. mutans colonies. The most effective CAL folium infusum to decrease $C$. albicans and $S$. mutans colonies is $22.5 \%$.

More experiments are needed to find out the biocompatibility of Coleus amboinicus, Lour folium infusum to be used as an alternative mouth wash.

\section{REFERENCES}

1. Wijayakusuma H, Dalimartha S, Wirian AG, Tanaman obat berkhasiat Indonesia IV. Edisi 1. Jakarta: Pustaka Kartini; 1996. p. $38-41$.

2. Heyne K. Tumbuhan berguna Indonesia. Jilid III. Jakarta: Badan Litbang Kehutanan. Yayasan Sarana Wana Jaya; 1987. p. 1698.

3. Hutapea JR. Pemeriksaan pendahuluan golongan kandungan kimia tanaman Coleus Amboinicus, Lour (Labiatae) asal Tawangmangu. Balai Penelitian Tanaman Obat Tawangmangu, Pusat Penelitian Farmasi, Badan Penelitian dan Pengembangan Kesehatan, Departemen Kesehatan RI; 1982. p. 389-94.
4. Devi R. Daya antimikroba ekstrak Coleus Amboinicus, Lour terhadap Candida Albicans pada resin akrilik. J Kedokteran Gigi Indonesia 2003; 10(edisi khusus):845-51.

5. Hammerschmidt FJ, Clark AM, Soliman FM, El-Kashoury ES, Kawy MM, Fishawy AM. Chemical composition and antimicrobial activity of essential oil of Jasonia Candicans and Jasonia Montana. Planta Med 1993; 59:68-70.

6. Rahardjo MB. Perbedaan daya antibakteri Allium Sativum Linn dan Kaempferia Galanga terhadap Streptococcus Mutans dan bermacammacam bakteri yang berasal dari saluran akar Gigi gangraena pulpae. Thesis. Surabaya: Universitas Airlangga; 1993. p. 13.

7. Kidd EAM, Bechal SJ. Dasar-dasar karies penyakit dan penanggulangannya. Essentials of dental caries. New York: The desease and its management. 1-8. Company; 1992. p. 676, 688-9.

8. Bahalwan R, Sjabana D. Mengkudu seri referensi herbal. Jakarta: Salemba Medika; 2002. p. 3.

9. Eha D. Khasiat obat kumur infusa daun Kacapiring terhadap perubahan mikroorganisme rongga mulut pemakai gigi tiruan lepasan. Majalah Ilmiah Kedokteran Gigi Fakultas Kedokteran Gigi Usakti 1999;Edisi khusus FORIL VI:497-501.

10. Dep Kes RI. Farmakope Indonesia. Edisi 3. Jakarta: Dep Kes RI; 1979. p. 12-13.

11. Regezi JA, Sciubba JJ. Oral pathology: Clinical pathologic correlation. Philadelphia: WB Saunders Company; 1989. p. 110-6.

12. Hugo WB, Russel AD. Pharmaceutical microbiology. $4^{\text {th }}$ ed. Oxford, London, Edinburgh, Boston, Melbourne: Blackwell Scientific Publications; 1989. p. 226-33.

13. Siswandono, Soekarjo B. Kimia medisinal. Cetakan I. Surabaya: Airlangga University Press; 1995. p. 247-8.

14. Robinson T. Kandungan organik tumbuhan tinggi. Padmawinata K. Edisi ke-6. Bandung: Penerbit FMIPA ITB; 1995. p. 191-222.

15. Melville PH, Russel C. Microbiology for dental student. $3^{\text {rd }}$ ed London: Williem Heinewmann Medical Book Ltd; 1981. p. 155-76.

16. Boedi S. Aspek klinis dan penetapan diagnosis kandidiasis mulut. Majalah Ilmiah Kedokteran. Gigi Fakultas Kedokteran Gigi Usakti 2001; 16(44):86-95.

17. Brightman VJ, Greenberg MS. Candidiasis. In: Lynch MA, editor. Burket's oral medicine diagnosis and treatmen. $8^{\text {th }}$ ed. Philadelphia: Lippincott; 1984. p. 223-7. 